\title{
Erasmus and His Amanuenses
}

\section{Citation}

Blair, Ann. 2019. Erasmus and His Amanuenses. Erasmus Studies 39 (1): 22-49. doi:

10.1163/18749275-03901011

\section{Permanent link}

http://nrs.harvard.edu/urn-3:HUL.InstRepos:41473796

\section{Terms of Use}

This article was downloaded from Harvard University's DASH repository, and is made available under the terms and conditions applicable to Open Access Policy Articles, as set forth at http:// nrs.harvard.edu/urn-3:HUL.InstRepos:dash.current.terms-of-use\#OAP

\section{Share Your Story}

The Harvard community has made this article openly available.

Please share how this access benefits you. Submit a story.

Accessibility 
Final author's manuscript for Ann Blair, "Erasmus and his amanuenses," Erasmus Studies 39:1 (2019), 22-49

Ann Blair, Dept of History, Harvard University; amblair@,fas.harvard.edu

\section{Erasmus and his amanuenses ${ }^{1}$}

Warm thanks for this invitation. The literature on Erasmus is so broad and so deep that contributing to it is an intimidating prospect. In particular the Erasmus field has been studying Erasmus as a writer and scholar and his working methods, his familia, and his relations with printers long before these topics started to develop elsewhere in the early modern field. That work dates back a full century to P.S. Allen's 1915 'Erasmus's relations with his printers" and fifty years ago Franz Bierlaire published an important book exactly on my topic: La familia d'Erasme. ${ }^{2}$ I have come to Erasmus through a back door -through my interest in amanuenses and secretaries or the hidden helpers of intellectual work in the Renaissance - and I am most grateful for the warm welcome and help I've received from many Erasmians along the way, with more to come I trust.

Erasmus offers an especially rich case in which to study amanuenses thanks to his exceptional stature as the prince of humanists and (not coincidentally) a remarkably abundant Nachlass (especially the correspondence with some 3141 letters). ${ }^{3}$ Franz Bierlaire explains that his study was inspired by the entry in P.S. Allen's index to the correspondence for "servant-pupils." By combing through the correspondence and adducing some other sources Bierlaire offered a nuanced portrait of Erasmus as a paterfamilias, the head of a household with neither wife nor children (Erasmus remained a cleric and celibate though he was released from his monastic vows), but a bustling one nonetheless, comprising a female housekeeper (Margarete Büsslin, from 1522 to 1536) and multiple young men (typically in their 20s) who lived with Erasmus to study with and help him. But at first Erasmus had no money and moved regularly, so only took on

\footnotetext{
${ }^{1}$ Warm thanks to William Barker, Jan Bloemendal, Reinhard Bodenmann, Anthony Grafton, Henk Jan de Jonge, Eric MacPhail, Silvana Seidel Menchi, Paolo Sachet, Alexandre Vanautgaerden, Jan Willem Klein for their generous and expert help in reading drafts, suggesting references, and answering queries.

2 P.S. Allen, "Erasmus's relations with his printers," Transactions of the Bibliographical Society 13 (1913): 297-322; Franz Bierlaire, La familia d'Erasme: Contribution à l'histoire de l'humanisme (Paris: Vrin, 1968).

${ }^{3}$ For Erasmus's correspondence see Opus epistolarum Des. Erasmi Roterodami, ed. P. S. Allen et al., 12 vols (Oxford: Oxford University Press, 1906-58), available through Oxford Scholarly Editions Online. For a complete French translation see $L a$ correspondance d'Erasme, tr. Aloïs Gerlo and Paul Foriers, 12 vols (Brussels: Presses Académiques européennes, 1967-84). For English translations of letters to March 1532: The correspondence of Erasmus, tr. R.A.B. Mynors and D.F.S. Thomson, annotated by Wallace K. Ferguson, in Collected Works of Erasmus vols 1-18 [vols 19-22 are in progress] (Toronto: University of Toronto Press, 1974-). I will refer to letters as "ep." followed by the letter number in Allen.
} 
boarding pupils occasionally. ${ }^{4}$ By 1508 his reputation was secure and his income buoyed by pensions and gifts and income from his publications (often in the form of copies of his books which he would sell or give away in expectation of countergifts). ${ }^{5}$ At its height, e.g. during his long stay in Basel 1521-30, the familia of Erasmus included up to eight other men. Some were convictores who paid for the privilege of sharing a roof and meals with Erasmus, although they too might help out - they came from all over Europe (from Poland to Portugal) to be a discipulus. One of them (Andrzej Zebrzydowski), who went on to become bishop of Cracow, commemorated his association with Erasmus on his tombstone more than twenty years later calling himself "magni illius Erasmi discipulus et auditor." Others were hired to help as servants (famuli or amanuenses); they were often recent graduates from Leuven recommended to Erasmus by his former teacher there Conrad Goclenius. They provided service "in the bedchamber and at the table" but also in the study, at the printer's shop correcting proof, and on the road.

The letters show Erasmus giving them directives particularly when they were sent on errands abroad, carrying letters and dedication copies of books, and tasked with collecting letters, pensions, or gifts that had been promised. Erasmus also wrote to them with advice and encouragement after they had left his house; typically he enjoined them to further study and prudent marriage, and employment in a printing house, or teaching students or writing books. ${ }^{8}$ We also learn about these helpers through the letters of recommendation that Erasmus wrote on their behalf, helping them secure new positions

${ }^{4}$ In 1498 Erasmus expected payment from these students in the amount of 32 crowns and one outfit per year; see ep. 82, 11. 1-4 and Jean Hoyoux, "Les moyens d'existence d'Erasme," Bibliothèque d'Humanisme et Renaissance 5 (1944): 7-59, p. 12. Thirty years later Andrzej Zebrzydowski (Zebridovius) paid $3 \frac{1}{2}$ florins per month to live in Erasmus's house; see ep. 2036 1. 6 and Bierlaire, 84. Given the multiple forms of proper names (e.g. vernacular and Latin) I generally follow those preferred by Pieter Bietenholz and Thomas Deutscher, Contemporaries of Erasmus. A Biographical Register of the Renaissance and Reformation, 3 vols (Toronto: University of Toronto Press, 1987), e.g. I, 237 (Büsslin), III, 473-74 (Zebrzydowski).

${ }^{5}$ Hoyoux, 42-48. See Jean-Pierre vanden Branden, "Erasme et l'argent," in Miscellanea Jean-Pierre vanden Branden. Erasmus ab Anderlaco (Brussels: Archives et Bibliothèques de Belgique, 1995), 465-96; and Eckhard Bernstein "Erasmus' Money Connection : The Antwerp Banker Erasmus Schets and Erasmus of Rotterdam, 15251536," Erasmus in English 14 (1985/86), 2-7.

${ }^{6}$ Bierlaire, 85; Bietenholz and Deutscher, III, 474.

${ }^{7}$ See the letter (9 July 1530) to Alfonso Valdes speaking of Quirinus Talesius: "famulus meus ... qui mihi et in cubiculo et in mensa perpetuo adfuerat" (ep. 2349, 11. 8-11); Bierlaire, 35.

${ }^{8}$ See for example his advice (10 Dec 1531) to Hilarius Bertholf to make a living from students and publications: "Si te Lugdunum conferres, aliquot discipuli alerent te, et nonnihil emolumenti veniret a typographis. Non omnibus est felix aula." Ep. 2581, 11. 1719; Bierlaire, 61. 
with other scholars, or in the Church, or at a court. ${ }^{9}$ In a different kind of letter, typically to close friends, Erasmus also vented about his famuli, wondering where they were, why they had not written, suspecting them of having left him, or of squandering his money, or of being spies sent by Lutherans to spread nasty rumors about him. Erasmus's friends Boniface Amerbach and Conrad Goclenius both tried to rein in the distrust that he was increasingly prone to in his later years. But that distrust had been fueled by some genuinely bad experiences: like the new housekeeper he took on in Freiburg who with an accomplice in the household had plans to make off with his furniture, or Quirinus Hagius whom he had sent to England to collect a pension but who never brought any money back. ${ }^{10}$ What angered Erasmus even more about Hagius is that he was heard claiming that Erasmus agreed with the reformer Oecolampadius, thus appropriating Erasmus for the Reformation. ${ }^{11}$ That experience led Erasmus to exclaim in 1534 that "no small part of my miseries have come from my servants." ${ }^{12}$ Similarly Erasmus became very angry with Nicolaas Kan (or Cannius, d. 1555), whom he otherwise liked, because Kan had stopped to visit Gerard Geldenhouwer in Strasbourg; Geldenhouwer had once been a friend but had become anathema to Erasmus after trying to associate him to the Reformation. ${ }^{13}$ In a time of acrimonious religious disputes the famuli were delegates of Erasmus and he expected them to represent his views according to his directives.

At the same time as he was demanding and easily suspicious, Erasmus could also be generous. He paid them 20-24 florins per year in addition to providing room and board. ${ }^{14}$ On top of that he made occasional gifts: e.g. 150 gold crowns to Quirinus Talesius in 1529 to thank him for several years of good service, ${ }^{15}$ or copies of his books, and occasional mention in print. In the two versions of his will from 1527 and 1536 Erasmus remembered a number of them (though others were disappointed), notably: Sigismundus Gelenius who was not an amanuensis but a trusted corrector at Froben's printing house (named in both wills); Philippus Montanus who had stayed for some time with Erasmus in 1528 and remained a helpful contact thereafter (only in the will 1536); and the

${ }^{9}$ For examples of recommendations: Bierlaire, 53, 71. More generally on this genre: B. van der Aa, “'Iuvenes gnavi, probi ac modesti' or the art of recommendation. An analysis of the correspondence of Ubbo Emmius and Janus Gruter," in Roma Magistri Mundi. Itineraria culturae medievalis. Parvi flores, ed. Jacqueline Hamesse (Louvain-la-Neuve: Fédération Internationale des Instituts d'Etudes médiévales, 1998), 367-82.

${ }^{10}$ Bierlaire, 92-95 for incidents of dishonesty, 70-71 for examples of suspicion, and 75, 94 for examples of Goclenius and Amerbach offering reassurance about his servants.

${ }^{11}$ Conrad Goclenius reported this to Erasmus in ep. 3037 of 10 August 1535. Erasmus wrote a letter to Joost Sasbout to correct this claim, which is mentioned in epp. 3052 and 3061, but is now lost. On Quirinus Hagius and his misdeeds see Bietenholz and Deutscher, III, 127.

12 "Nec minima pars molestiarum venit a famulis." Ep. 2976 (13 Nov 1534 to John de Pins); Bierlaire, 95; Bietenholz and Deutscher, II, 82-84 and 252-53.

${ }^{13}$ Ep. 2356 (31 July 1530 to Viglius Zuichemus and Charles Sucquet); Bierlaire, 75.

${ }^{14}$ That's the rate Erasmus promises to Cornelius Grapheus whose help he requests in recruiting someone; ep. 2916 (13 March 1534); Bierlaire, 23-24.

${ }^{15}$ Ep. 2113 (6 March 1529); Bierlaire, 68. 
principal servant in place at his death: Quirinus Talesius was named in the will of 1529 and Lambert Coomans in 1536 indeed received 200 gold florins when Erasmus died later that year. ${ }^{16}$ Bierlaire creates a masterful portrait of Erasmus in his household: by turns demanding and encouraging, arrogant and caring, stingy and generous.

What has changed in the last fifty years? Scholarship on Erasmus has grown apace: the Latin "Amsterdam" edition (ASD) is nearing completion (with the remaining twelve volumes underway) and the Complete Works of Erasmus (CWE) are making good progress. Meanwhile new currents in early modern cultural history have come around to topics that Erasmians have long appreciated. After Steven Shapin's seminal article of 1989 on Robert Boyle's reliance on but effacement of his laboratory assistants in the midseventeenth century, work in history of science has continued to expand our awareness of contributions to knowledge-making from "non-canonical" quarters. ${ }^{17}$ Recent work has documented the contributions of women and families, merchants and agents, servants and slaves in many fields of learning, including natural philosophy and medicine, antiquarianism, and scholarship. ${ }^{18}$ In parallel developments in literature and art history we are newly aware of the many people who participated in creating Renaissance art in many media, and of the collaborations that could be involved in the writing of plays, poems, and novels. ${ }^{19}$ Historiography on the circulation of information has emphasized how people, letters, books, images, natural specimens, and objects travelled across Europe and around the globe in growing numbers. These exchanges fostered collaboration even across considerable distances and helped to form both the reality and the idea of an international Republic of Letters. Finally, book history has taken off in recent decades, emphasizing that "authors don't make books, printers do"-- along with the many specialists they employed (including correctors, editors, indexers)-- so that a

${ }^{16}$ These two wills are conveniently available in Gerlo and Foriers, VI, 537-41 and XI, 367-69. On these men see Bietenholz and Deutscher, II, 84-85 (Gelenius) and 448-49 (Montanus), and III, 306-7 (Talesius).

${ }^{17}$ Steven Shapin, "The Invisible Technician,” American Scientist 77:6 (1989), 554-63. See also The Cambridge History of Science, vol. 3: Early Modern Science, ed. Katharine Park and Lorraine Daston (Cambridge: Cambridge University Press, 2006), part II: "Personae and Sites of Natural Knowledge."

${ }^{18}$ For further citations from this extensive literature see Ann Blair, "New KnowledgeMakers" in New Horizons for Early Modern Europe, ed. Blair and Nicholas Popper, forthcoming Johns Hopkins University Press.

${ }^{19}$ On collaborations in art see Svetlana Alpers, Rembrandt's Enterprise: the studio and the market (Chicago: University of Chicago Press, 1988), e.g. 59; William E. Wallace, Michelangelo at San Lorenzo (Cambridge: Cambridge University Press, 1994), e.g. 38; or the many collaborators described in Amanda Wunder, Baroque Seville: Sacred Art in a Century in Crisis (University Park PA: The Pennsylvania State University Press, 2017). For an entry into the large historiography on literary collaboration, see for example Margaret Ezell, "Afterword: 'her book' and early modern modes of collaboration," in Gender, Authorship and Early Modern Women's Collaboration, ed. Patricia Pender (Cham: Palgrave Macmillan, 2017), 245-58; Qui écrit? Figures de l'auteur et des coélaborateurs du texte, XVe-XVIIIe siècle, ed. Martine Furno (Lyon: ENS Éditions, 2009). 
printed book always involved the work of many (also when an author chose not to engage closely with the operations of the printing house). ${ }^{20}$

These currents have renewed attention to Erasmus's working methods. ${ }^{21}$ Lisa Jardine highlighted Erasmus's savvy use of media in her groundbreaking Erasmus Man of letters some 25 years ago. ${ }^{22}$ Mark Vessey and Hilmar Pabel emphasized in response that Erasmus was imitating Jerome's own careful attention to managing the diffusion of his scholarly works and reputation in the manuscript culture of the early Christian era. ${ }^{23}$ So how exactly did printing affect the practices that Erasmus sought to emulate from Jerome's time? Recent books by Alexandre Vanautgaerden and Valentina Sebastiani have returned to the massive topic of Erasmus and his printers, first broached by Allen. ${ }^{24}$ With a corpus of $130+$ works there's still much to ferret out through close attention to surviving copies. ${ }^{25}$ Recent digitization projects like the Swiss E-rara and Munich's MDZ increasingly make such book historical investigations possible even without access to a strong collection of Erasmus imprints. While it cannot convey all the clues present in a physical book, a high quality digitization offers more direct insight into the original form of Erasmus's publications than modern reprints and editions; the latter are invaluable for their expert annotations and commentary, but they often omit paratexts considered incidental or separate them from the work with which they appeared. ${ }^{26}$

${ }^{20}$ The maxim is attributed to Roger Stoddard in Hugh Amory, "The Trout and the Milk: an ethnobibliographical talk," Harvard Library Bulletin new series 7.1 (1996): 50-65, p. 63. For recent work on this perspective see Roger Chartier, The author's hand and the printer's mind (Cambridge: Polity Press, 2014); and Anthony Grafton, The Culture of Correction in Renaissance Europe (London: British Library, 2011).

${ }^{21}$ See most specifically Ueli Dill, "Die Arbeitsweise des Erasmus," Nederlands Archief voor Kerkgeschiedenis / Dutch Review of Church History 79:1 (1999): 1-38; Egbertus van Gulik, Erasmus and His Books, tr. J.C. Grayson, ed. James K. McConica and Johannes Trapman (Toronto: University of Toronto Press, 2018), ch. 6.

${ }^{22}$ Lisa Jardine, Erasmus Man of Letters (Princeton: Princeton University Press, 1993); in her preface to the new printing of 2015 Jardine mentions Bierlaire.

${ }^{23}$ Mark Vessey, "Erasmus' Jerome: the publishing of a Christian author," Erasmus of Rotterdam Society Yearbook 14 (1994), pp. 62-99; Hilmar Pabel, Herculean Labours: Erasmus and the Editing of St Jerome's Letters in the Renaissance (Leiden: Brill, 2008), e.g. 4-8.

${ }^{24}$ Alexandre Vanautgaerden, Erasme typographe (Geneva: Droz, 2010); Valentina Sebastiani, Johann Froben, printer of Basel (Leiden: Brill, 2018).

${ }^{25}$ Erasmus was prolific in so many different genres, including editions and contributions to the works of others and multiple enlarged editions of his own works, that it is impossible to settle on an exact count of his publications without carefully defining what one is counting. For detailed bibliographical work see Ferdinand van der Haeghen, Bibliotheca Erasmiana: répertoire des oeuvres d'Erasme, 3 vols (Nieuwkoop: B. de Graaf, 1961; first published 1893); and Vanautgaerden, Erasme typographe, 499-526.

${ }^{26}$ For example Allen interfiled Erasmus's published dedications and statements "to the reader" by date within the correspondence. He felt that in doing so he was following Erasmus's own wish (who indeed included some dedicatory letters in his printed 
I will approach Erasmus's work with his amanuenses from a book historical perspective, by examining first when and why amanuenses appeared in print in Erasmus's work, and then by considering surviving evidence of Erasmus's work with helpers available in manuscripts and annotated books. What is surprising from the perspective of Shapin's "invisible technician," is that Erasmus's famuli are not in fact always hidden -they appear in print, in letters that were meant to be circulated beyond their recipients, as well as in private letters and working manuscripts.

\section{The allure of print}

Print gave new force to a long sought after goal of gaining immortality through writing. The last of Erasmus's Epigrammata (1518) is a poem to accompany the gift of a reed pen to Wilhelm Nesen: the quill seeks to be preserved "lest I, who made so many names known to posterity, names never to be wiped out in the long course of time, should perish in obscurity." ${ }^{27}$ Erasmus mused there on the power of writing, which printing enhanced with a promise of faster, broader, and redundant diffusion. Erasmus was keenly aware of that power: in his first will he identified a dream team of correctors to oversee the publication of his works with Froben and called for his opera to printed in at least 1500 copies, twenty of which were to be donated to patrons and libraries he specified, as marks of friendship no doubt, but which would also ensure their preservation through distribution to prominent owners. ${ }^{28}$ Erasmus succeeded better than any humanist of his time in creating reputation. Mark Vessey has rightly pointed out that printing was not his only tool - he learned many tricks from Jerome, who had carefully built an international reputation in the manuscript era of the $4^{\text {th }}$ century. ${ }^{29}$ But printing created new opportunities for publicity-- for authors, and for their associates, particularly thanks to the habit of abundant paratexts. Many were eager to be associated with Erasmus. Zebrzydowski did so in his epitaph for example. Another desirable method was to appear in print in a book by Erasmus: being a dedicatee was a particularly valuable spot; one could also contribute a liminary poem, or simply get a mention.

collections of letters); see P.S. Allen, Opus epistolarum Des. Erasmi Roterodami, tome 1 (1484-1514) (Oxford: Clarendon Press, 1906), vi. The brief statements "to the reader" were then omitted from the editions of the works. Similarly the indexes to Erasmus's Adages and the prefatory blurbs to them that Erasmus composed were not included in the modern editions or translations of the Adages; but they have now appeared in William Barker ed. and tr., "Indexes to Erasmus' Adages," in CWE 30 (2016), 367-778.

${ }^{27}$ Erasmus, Epigrammata, published with Thomas More, De optimo Reip. Statu, Deque nova insula Utopia (Basel: Froben, 1518), 355; tr. Clarence H. Miller, ed. and annot. Harry Vredeveld, CWE 85 (1993), 134, \#61.

${ }^{28}$ Gerlo and Foriers, VI, 539-40; on this point see Karine Crousaz, Erasme et le pouvoir de l'imprimerie (Lausanne: Antipodes, 2005), 95.

${ }^{29}$ Mark Vessey, “Erasmus’s Jerome,” Erasmus Studies 14:1 (1994), 62-99. 
Amid grandees like bishops and princes Erasmus included only a few members of his familia as dedicatees. Erasmus wrote short dedications to two of his students in a composite book principally authored by Eobanus Hessus in $1519 .{ }^{30}$ He also singled out two of his convictores by dedicating his translation of Plutarch, De vitiosa verecundia (appended to De Lingua, 1526) to Frans van der Dilft, and two works to Karel Utenhove (Chrysostomi opuscula, 1529, and the revised edition of De pronuntiatione, 1530). ${ }^{31}$ Wilhelm Nesen was another member of Erasmus' circle in 1516 when Erasmus dedicated the second edition of De copia to him. ${ }^{32}$

As for commendatory odes, I have not yet managed a full investigation (which might well yield interesting results ${ }^{33}$ ), but we get some insight into the possible dynamics from a letter to Aldus Manutius of 1507. Erasmus explained there that he had sought to play a trick on a young Frenchman "who was in my service at the time, and whom I had persuaded by way of a joke that his poem would be published. When I left I gave it to [the printer Josse] Bade in the young man's presence, in order to keep his expectation alive.” But then Bade actually printed the poem, to Erasmus's exasperation and surprise. Erasmus wished to correct that error in the second edition of the work under preparation, by asking Aldus to "please leave out the short poem added at the end of the Tragedies" when reprinting them. ${ }^{34}$

Gilbert Cousin (1506-72), who worked for Erasmus for five years before leaving him in 1535, scored the biggest success on this front. ${ }^{35}$ A Latin poem and Greek distich of his were printed in Erasmus's Ecclesiastes, a manual about preaching, printed soon after August 1535 (judging from the dedication). Cousin's poems accompanied a medallion image of Erasmus which had appeared in the Adages of 1533 but with a different (unattributed) quatrain. ${ }^{36}$ But Cousin's poems were dropped, along with the medallion,

${ }^{30}$ Dedications to Joannes Draco and Henricus Bemyng in Helius Eobanus, A profectione ad. Des. Erasmum Roterodamum hodoeporicon [Louvain, 1519], sig. d3v-d4r. See Bietenholz and Deutscher, I, 144 (on Beyming). Hoyoux, 37.

${ }^{31}$ Ep. 1663 (3 Feb 1526 to Dilft) and epp. 2093 (1 Feb 1529) and 2209 (1 Sept 1529) to Utenhove. See Bietenholz and Deutscher, I, 392-93, and III, 362-63.

${ }^{32}$ Ep. 462; Bietenholz and Deutscher, III, 12-14.

${ }^{33}$ See for example the elegy on the death of Froben by Hilarius Bertholf cited and discussed in Alexandre Vanautgaerden, "L'oeuvre 'latin' de Jean Froben, imprimeur d'Erasme," in Emmanuel Bury ed., Tous Vos Gens A Latin. Le latin, langue savante, langue mondaine (XIVe-XVIIe siècles) (Geneva: Droz, 2005), 309-330, p. 324. On Bertholf, Bietenholz and Deutscher, I, 141-42.

${ }^{34}$ Ep. 209 (Nov 1507 to Aldus Manutius), 11. 56-61; tr. R.A.B. Mynors and D.F.S. Thomson, CWE 2 (1975), 137. See Bierlaire, 108. The young man is identified as Gervasius Amoenus by Gerlo and Foriers, and in Bietenholz and Deutscher, I, 51. ${ }^{35}$ Lucien Febvre, "Gilbert Cousin, secrétaire d'Erasme," Bulletin de la Société d'histoire du protestantisme français (1907), 97-158.

${ }^{36}$ As reproduced in Adagiorum chilia prima, ed. M. L. van Poll-van de Lisdonk, M. Mann Phillips, Chr. Robinson (Amsterdam: North-Holland, 1993), ASD II-1, [4]. 
when the Ecclesiastes was reprinted less than a year later, in March $1536 .{ }^{37}$ The title page of that imprint announced a superior index in that second edition, but a major change had occurred in Erasmus's feelings toward Cousin in the interim. Over the summer 1535 Cousin had played a crucial role in Erasmus's move back to Basel from Freiburg. ${ }^{38}$ Although Erasmus knew of Cousin's pursuit of a canonry in his hometown of Nozeroy in nearby France, he likely expected that Cousin could be convinced to stay in his employ. But by the end of 1535 Cousin had settled in Nozeroy, eliciting from Erasmus a combination of lures to Cousin to return to Basel and complaints about Cousin's parents for discouraging that. ${ }^{39}$ In his anger and disappointment at Cousin's departure Erasmus may have called for Cousin's poems to be removed. But if Cousin was stung by their removal in 1536, he was able to reuse the material after Erasmus's death in a publication of his own in $1553 .{ }^{40}$

In another case we learn that one of Erasmus's amanuenses, Nicolaas Kan, had requested to feature in the Colloquies. Erasmus obliged in 1529 by composing "The Cyclops or gospel-bearer," a colloquy which mocked religious hypocrisy, but also poked fun at members of his household. The title likely alluded to Pieter Meghen, whom Erasmus had earlier hired as a skilled scribe and courier and called "Cyclops" among other nicknames because he had only one good eye. ${ }^{41}$ But the colloquy made no other mention of him; instead it featured two men in Erasmus's employ at the time: Cannius, the Latin name for Kan, and Polyphemus, the nickname of Felix Rex, who was portrayed as a heavy

${ }^{37}$ Confusingly the two imprints carry the same basic information on the title page: Erasmus, Ecclesiastae sive de ratione concionandi libri quatuor (Basel: Froben, 1535) and the same dedication dated Nones of August 1535. The earlier imprint, with a colophon dated August 1535, has this continuation of the title: "opus recens, nec antehac a quoquam excusum" and includes the medallion and poems. These appear facing the first page of text, on the verso of the blank page following the dedication; see Folger Library 186-581f, sig. [a4v]. The later imprint has this addition to the title: "opus recens, denuo editum, sed cum indice accuratiore quam antehac et copiosiore" and a colophon dated March 1536. Interestingly the medallion and poems also appeared in an octavo edition published in Antwerp: Michael Hillenius, 1535; copy in BnF réserve D.15240.

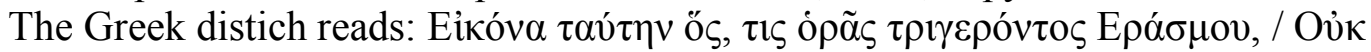

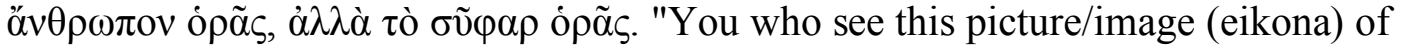
thrice-aged Erasmus, You see not a man, but the wrinkled skin." With thanks to Nathanael Aschenbrenner for this translation.

${ }^{38}$ For example Cousin drew up an inventory of Erasmus's goods in April 1534: Universitätsbibliothek (UB) Basel, shelfmark CVIa71.

${ }^{39}$ Ep. 3104 (11 March 1536 to Gilbert Cousin).

${ }^{40}$ Effigies Des. Erasmi ... et Gilberti Cognati (Basel: Oporinus, 1553), 10-11; the Latin quatrain features two small changes. And in Cousin's annotated copy of the work at the UB Basel (shelfmark AA VI.27a), the Greek verse has been annotated with new wording, presumably by Cousin himself.

${ }^{41}$ On Meghen see J.B. Trapp, "Notes on Manuscripts written by Peter Meghen," The Book Collector 24 (1975), 80-96, and "Pieter Meghen 1466/7-1540 scribe and courier," Erasmus in English 11 (1981-82), 28-36. Bietenholz and Deutscher, II, 420-22. 
drinker. ${ }^{42}$ Erasmus explained these references and their origin in Kan's request in a letter to the Basel Reformer Oecolampadius which sought to dispell a rumor, apparently begun by workers at the Froben press, that the colloquy was an attack on him. The apology might not have sufficed to erase the tensions between Erasmus and Basel's leading reformer-Erasmus moved to Freiburg soon afterward. But it gives us a precious rare echo of a servant's voice. Kan's request to be included in a publication is not the only such I have encountered. In a scholarly book on etymology printed in 1603 Pontus de Tyard explained that his "calligraphus a manu" Chaumont had asked to have his observation of an unusual "partridge stone" (perdicite) included in the book manuscript that he was copying. Since the author obliged, we are aware in this case too of the interest of an amanuensis in being mentioned in print - even if the mentions were made with some ironic distance in the case of Pontus de Tyard and a good dose of mockery in Erasmus's Colloquies. ${ }^{43}$

Famuli came up repeatedly in the controversy with Edward Lee in which Erasmus wanted to emphasize that Lee had been of no use to him. Erasmus first invoked the testimony of his famuli, whom he named, to rebutt Lee's charges that he had relied on Lee's work: Joannes Phrysius and Jacobus Nepos could confirm that Erasmus started to revise his New Testament in Antwerp before any contact with Lee, and Ioannes Hovius and Jacobus Nepos that he had requested no changes to the manuscript after his encounter with Lee. In any case, Erasmus concluded that he had no reason to mention Lee since "others too had brought to my attention much more important things, whom I nevertheless have not ventured to name. If I had had to declare the names of all from whose advice this edition derived some benefit, I would have had to give an honourable mention to my assistants, to whom I gave the task of restoring order in the annotations or occasionally of comparing the Greek with the Latin." 44 Erasmus was likely playing here

${ }^{42}$ Ep. 2147 (10 April 1529 to Oecolampadius), 11. 11-20. On Polyphemus or Felix Rex see Bietenholz and Deutscher, III, 150. For the colloquy see ASD I-3, 603-9. The colloquy ends with a pun on Cannius/Kan's name "Ne me vincas officio, precor ne Cannium vnquam destituat, vnde cognomen sortitus est." See tr. Craig R. Thompson CWE 40, (1997), 870: "I pray that Cannius, as the name implies, may never lack a can!" (punning on Kan for 'mug' or 'cup'); also possible: "I pray that Cannius is never deserted by the origin of his name" with a play on "kann," for his ability to do things.

${ }^{43}$ See Pontus de Tyard, De recta nominum impositione (Lyon: Roussin, 1603), 80-81. For a modern edition and French translation see Pontus de Tyard, Oeuvres complètes, t. 7: La droite imposition des noms, ed. Jean Céard and Jean-Claude Margolin (Paris: Champion, 2007), 198-99 and the notes 442-43. I am most grateful to Jean Céard for giving me this reference. For more discussion see Blair, "New Knowledge-Makers." Erasmus also made fun of his housekeeper Margarete Büsslin in a colloquy published in 1523 (“Convivium poeticum” ASD I-3, 344-59); see Bietenholz and Deutscher, I, 237. ${ }^{44}$ Erasmus, Apologia qua respondet duabus invectivis Edwardi Lei (Antwerp: Hillenius, 1520), ASD IX-4, 24-48, p. 39; tr. Erika Rummel, CWE 72 (2005), 23. See also Erasmus, "Apologie," tr. Alain Van Dievoet, in Alexandre Vanautgaerden, Les invectives (Brussels: La Lettre Volée à la Maison d'Erasme, 1997), 81; Bierlaire, 29. See COE 2:208 (Hovius); 2:232 (Johannes Phrysius), 3:11-12 (Nepos). 
on the expectation that a scholar of his stature would rely on the work of helpers but never mention them. In naming them and their specific activities contrary to the norm, Erasmus was also enacting as well as explicitly making the point that Lee was no more worthy of mention than Erasmus's servants. In this way Erasmus hoped to ensure that Lee could not derive prestige from having engaged the great humanist in controversy.

In sum only a handful of Erasmus's amanuenses figured by name in his publications, most often as an aid to mocking an opponent --whether Gervasius Amoenus, religious hypocrites, or Edward Lee.

\section{The anxiety of print.}

The flipside of the allure of print and the chance for wide and long diffusion of an honorable mention of one's name, was the risk of equally wide and long diffusion of something that would bring ill repute. Erasmus was a prolific author in print, composing in haste and in abundance, but he was not immune to the anxieties inherent in sending a work out to an unknown audience, particularly in times of strident religious disputes. In allaying those anxieties amanuenses could prove useful - as excuses to publish, as mouthpieces, or as intermediaries who could take the blame for errors. The servants were never named in these instances, which would have been invidious even if the responsibility attributed to them were true; the point was to use the "servant-function" as a minimizer of authorial responsibility. The "servant-function" could take a variety of forms in early modern Europe, many of which Erasmus pioneered.

\section{The trope of the thieving servant}

Erasmus is famous for floating works with plausible deniability before embracing them as his own. Already in a preface of 1515 Erasmus complained about how often something was attributed to him that he did not write or did not write for publication. He suggested in particular that his epigrams were published without his authorization: "some servant, I suspect, filched them, and sold them to the printers." Since the printer involved (Josse Bade) was one Erasmus continued to work with this hardly seems convincing..$^{45}$ This kind of prefatory disclaimer was a commonplace, along with "my friends begged me to publish" and other variants. But the claim worked because it was also plausibleErasmus probably did experience the unauthorized publication or attribution of some manuscripts. The trope of the thieving servant served to minimize the author's responsibility for a specific publication, and to apologize for the haste with which it was produced, at the same time as it could suggest a real occurrence. ${ }^{46}$

Servants as mouthpieces

Studies of early modern polemics in the Republic of Letters have highlighted a

${ }^{45}$ Ep. 341 (30 July 1530, "to the reader" in Absolutissimus de octo orationis partium constructione libellus, Froben, 1515); tr. R.A.B. Mynors and D.F.S Thomson, CWE 3 (1976), 146. See Vanautgaerden, Erasme typographe, 224.

${ }^{46}$ Vanautgaerden identifies different categories of publication of Erasmus' works, including "surreptitious" and "surreptitious but acknowledged by Erasmus" in Erasme typographe, 499. 
widespread code of conduct in polemics, formed around the central principle that you showed your superiority to your opponents by not responding to them. By entering into dispute with someone you acknowledged them as an equal. ${ }^{47}$ So the Ciceronians like Alciato and Bembo whom Erasmus attacked for their excessive lionization of Cicero simply ignored Erasmus in return. But Julius Caesar Scaliger took up the cause and attacked Erasmus in 1531. He commented that in refusing to reply to him, Erasmus was insulting him in turn. Erasmus would not deign to reply since "even those whom he attacks with hostility are consecrated to immortality through him." 48

As a result leaving to helpers the task of responding to enemies was a strategy explicitly recommended to Erasmus by one of his correspondents. Johannes Cochlaeus, himself an expert polemicist against Lutherans, wrote to Erasmus who was smarting from some Lutheran attacks in March 1529: "So pay no attention to the pointless baying of your critics, whoever they may be. Continue to produce those works of yours, which envy cannot touch and no one apart from you can write. Ask lesser men and your own assistants to answer those worthless nobodies, so that you may spend your time on more important things. Your man Quirinus [Talesius] will be able to do them full justice. Or if you prefer, have something published under the name of your cook, which will properly defend your honor while poking fun at them and treating them with contempt. I do not think them worthy of either your praise or your censure." 49

I am not aware that Erasmus ever planned such an elaborate ruse, but he certainly had helpers who aided him in pursuing his causes. Wilhelm Nesen for example, who had published attacks against the conservative Catholics of Louvain, was tapped to write a letter to Amerbach wondering who the author of the Julius exclusus might be (even though they both knew it was Erasmus) - Silvana Seidel Menchi has beautifully pointed out how this kind of "double register letter" was meant to be leaked to others to deflect attention from Erasmus in the hunt for the author of this daring satire. ${ }^{50}$ And Erasmus enlisted others to block access to printers to his enemies (like Lee), or to leak information about upcoming publications so that he could respond to them as they appeared (e.g. in the case of the Hyperaspistes against Luther). ${ }^{51}$

Servants to take the blame

${ }^{47}$ Isabelle Pantin, "La querelle savante dans l'Europe de la Renaissance. Éthique et étiquette," Enquête 5 (1997), paragraph 14.

${ }^{48}$ Julius Caesar Scaliger, Oratio pro M Tullio Cicerone contra des. Erasmum, 1531: Adversus Des. Erasmi Roterod. dialogum Ciceronianum oratio secunda, 1537, ed. and tr. Michel Magnien (Geneva: Droz, 1999), 320-21; and see Pantin, note 27.

${ }^{49}$ Ep. 2120 (13 March 1529), 11. 38-45; tr. Alexander Dalzell, CWE 15 (2012), 128-29. Disregarding his own advice Cochlaeus was a "leading Catholic controversialist" who responded in print to many critics; see Bietenholz and Deutscher, I, 321-22.

${ }^{50}$ Erasmus, Julius exclusus, ed. Silvana Seidel Menchi, ASD I-8 (Leiden: Brill, 2013), 48.

${ }^{51}$ Vanautgaerden, Erasme typographe, 429, 494. 
Errata lists were typically used to acknowledge and fix errors but could serve, as Brian Richardson has shown, as a place to foist (or occasionally accept) blame for them. ${ }^{52}$ Erasmus modelled the detailed list of errata spanning more than one folio page in a few editions of the Adages published by Froben (e.g. 1523 and 1526), in order to flag corrections not only for readers but also for future editions. In other cases Erasmus issued short apologies. In his Ecclesiastes of 1535, for example, a rather short list of errata is accompanied by a "to the reader" with a complex assessment of responsibility:

Many [authors] like to blame their errors on the work of the printers. But I frankly admit that almost all the errors in this work must be attributed either to my amanuensis or to myself. It is true that I was present during the printing, but because of my poor health I was unable to make a final revision, especially since the need to correct certain pages often coincided with the hours that had to be devoted to sleep or to the care of my poor body. There was however no need for my help since that task was vigilantly carried out by Sigismundus Gelenius, a man of great learning and taste. But when I had the leisure to read over some of the printed pages, I discovered several places that had slipped through my revision. There is not a huge number of these if you take into consideration the great length of the work, very few, if you discount trivial errors. I thought I should add a note here to this effect. ${ }^{53}$

This "to the reader" cum errata list was designed to deflect blame away from the printer; quite unusually it included explicit thanks to the corrector Gelenius (whom Erasmus also thanked in print in 1529 and remembered in his will), even while listing some errors that Gelenius had not caught. ${ }^{54}$

The following year Erasmus again used a closing "to the reader" as an equivalent to an erratum. In the last edition of the Adages to appear in his lifetime, dated March 1536, in the place where an errata list would be expected, Erasmus offered instead a paragraph of complaint:

In the proverb "dimidium plus toto" one must suppress the words from "Suidas citat ex Marino..." to "Regum igitur etc". Indeed they are suppositious and have nothing to do with this passage. I once had a secretary who took pleasure in

\footnotetext{
52 Brian Richardson, Print Culture in Renaissance Italy: the editor and the vernacular text 1470-1600 (Cambridge: Cambridge University Press, 1994), e.g. 12; see also Ann Blair, "Errata lists and the reader as corrector," in Agent of Change: Print Culture Studies after Elizabeth L. Eisenstein, ed. Sabrina Alcorn Baron, Eric N. Lindquist and Eleanor F. Shevlin (Amherst and Boston: University of Massachusetts Press, in association with The Center for the Book, Library of Congress, Washington D.C., 2007), 21-41.

${ }^{53}$ Erasmus, Ecclesiastae (1535), last page (Folger Library copy). Reproduced as Ep. 3044 rather than in ASD V-4/5; translation from "The Evangelical Preacher," tr. James L.P. Butrica, CWE 67 (2015), 247. Bierlaire, 30 n. 43.

${ }^{54}$ For his earlier praise of Gelenius, see ep. 2019, 11. 18-24 (dedicatory epistle to Piotr Tomicki, in Senecae opera, Basel: Froben, 1529).
} 
adding secretly without my knowledge something of his own in my works. This passage from Suidas that I cited in "principium dimidium totius" where it belonged. But whether by forgetfulness or ignorance he added this passage here where it is completely inappropriate. ... I ask you, reader, is that behaving like a secretary or rather like a falsifier? ... I have caught other such impostures elsewhere when in reviewing the text I was offended by wild interpolations. Since this was added to the text without my knowledge I was not able to notice it and the error would have gone on forever had not a shocked corrector shown me the passage. ... Let's hope that this man did not play tricks on other passages. If he had been my mortal enemy what could he have done to me that is worse than exposing me to the mockery of the learned? $?^{55}$

Here Erasmus pinned the blame for a sentence he considered to be out of place on an unnamed helper. But that sentence had been present in editions of the Adages since 1526. Indeed it appeared as an addition that Erasmus made in his own hand in a copy of the Adages of 1523 that Erasmus and Kan annotated in preparation for the following edition. ${ }^{56}$ But the corrector in 1536 (perhaps Gelenius) evidently raised a question about it. Is that why Erasmus suddenly decided the sentence was misplaced without remembering that he had added it himself more than ten years before? Or was Erasmus trying to settle a score with an earlier amanuensis --notably Kan who worked on the editions of 1523 and 1526 and had gone to visit Geldenhouwer inappropriately? What were in fact the various purposes of an erratum?

First, any errata list tacitly requested that readers enter these corrections into their personal copies. Occasionally I have come across early modern readers who did so methodically, but not very often. The printed errata list was perhaps especially useful to guide the printer of a subsequent edition, and the fact that Erasmus's works were so often reprinted may have motivated Erasmus to take the collection of errata more seriously than many authors. In fact the Froben printing house did carry out the change that Erasmus requested in 1536 and dropped the offending sentence in the following edition of the Adages in 1540 and in subsequent ones. ${ }^{57}$

But the erratum note of 1536 also served as a warning that other interpolations may have been made without Erasmus's knowledge or authorization. It created a blanket disclaimer against anything a reader might find incongruous, which could be chalked up to the dishonest servant at work again.

\footnotetext{
${ }^{55}$ Ep. 3093 (c. February 1536). The editor notes "The Regum igitur sentence, which appears in 1526, would seem to be an addition made by Erasmus himself in that year." ${ }^{56}$ [Adagiorum opus] (Basel: Froben, 1523), 287 (adage 895); copy in private hands. I am grateful to the ASD team for the opportunity to consult a microfilm.

57 Though CWE and ASD took note of this final erratum, one modern edition has kept the offending passage: Adages, ed. Jean-Christophe Saladin, 5 vols. (Paris: Les Belles Lettres, 2011), I, 658.
} 
Finally, this last note in what turned out to be the last edition of the Adages, that most malleable and infinitely expandable kind of text, served to assert Erasmus's moral claim to the integrity of his writing. It was a warning to anyone who would presume to make changes to the Adages that to do so would be against Erasmus's wishes. ${ }^{58}$ While the vehemence of Erasmus's closing paragraph in 1536 is striking, the concerns he articulated were not unusual for him. Erasmus complained elsewhere of those who changed ancient texts as they edited or commented on them, as Karine Crousaz has pointed out. ${ }^{59}$ In his own editorial work on the Opera of Jerome, Erasmus worked hard to identify the works falsely attributed to the Church Father and listed them separately in the table of contents. He also closed this detailed list of contents of the multi-volume edition with an injunction conspicuously printed in capital letters arranged in an hourglass shape; the injunction, copied from Jerome who had copied it from Irenaeus, summoned future copyists and editors to transmit the original texts with faithful care and to carry forward the exhortation to textual fidelity in turn. ${ }^{60}$ Just as Erasmus was concerned about the integrity of Jerome's oeuvre, he worried about safeguarding the integrity of his own works. In his will of 1527 Erasmus called for the publication of his own opera by Froben and a team of expert correctors (whom he recommended for the task by name) and enjoined them to intervene in his texts only to rectify only patent errors, without adding observations of their own. Erasmus's anxiety about the risk of interpolations being introduced in the transmission of his works did not diminish with age. In 1535 he fretted to a correspondent : "I know only too well how unscrupulously the works of dead authors are treated." ${ }^{\prime}$ Erasmus's show of anger at the modifications that could be made by amanuenses and scribes was informed by his experience as an editor and and his fears as an author.

Erasmus's final erratum of 1536 left no doubt about the author's wishes, but it had limited impact. In keeping with the fate of errata once the corrections they called for had been made, this one was dropped from later editions and thus not viewable in the long term. Even in his lifetime the Adages had spiraled out of Erasmus' control. Their huge commercial success included not only multiple folio editions published by Froben under Erasmus's supervision, but also scores of other editions, often in smaller formats, abridged and re-arranged. Given the additive nature of the genre, new adages could easily be inserted, with or without explicit mention of their non-Erasmian source. ${ }^{62}$ Some

\footnotetext{
${ }^{58}$ Crousaz, 96-97.

${ }^{59}$ Ep. 1334 (5 January 1523, preface to the edition of St Hilary, addressed to Jean Carondelet), 11. 108-25; tr. R.A.B. Mynors, CWE 9 (1989), 248-49. See Crousaz, 93.

${ }^{60}$ Erasmus explained that the injunction was Irenaeus's originally which Jerome placed at the start of his edition of the Chronicle of Eusebius. See Jerome, Opera (Froben, 1516), I, sig. gammar 6r; discussed in Vessey, "The Publishing of a Christian Author," p. 95. ${ }^{61}$ Gerlo and Foriers, VI, p. 538 (\#1779A). "Haud ignarus quam parum bona fide tractentur defunctorum lucubrationes." Ep 3016 (7 May 1535 to Julius Pflug), 1l. 25-30; translated in the introductory note CWE 67: 91.

${ }^{62}$ See for examples of editions that announced the addition of Cousin's adages : Adagiorum Erasmi chiliades quatuor... Hic accesserunt ... Gilberti Cognati Adagiorum sylloge (Cologne: Petrus Aubertus, 1612); Adagiorum chiliades... quibus praemissi sunt
} 
editions kept Erasmus's adages intact even as they boasted of adding new proverbs collected by others (including Erasmus's former amanuensis Gilbert Cousin), others were less scrupulous. Neither Jerome's injunction printed in 1516 nor Erasmus's vehement "erratum" of 1536 could prevent the transformation of texts in the course of their transmission, but both provide good evidence of the enduring anxiety of authors about losing control of their works through publication.

Erasmus valued control over his textual production, yet he also needed help. In complaining about the interpolation of an amanuensis in the huge bulk of the Adages, Erasmus acknowledged that he did not compose the work alone. Manuscript evidence can offer further insight into how Erasmus worked with his amanuenses.

\section{Evidence of collaboration from manuscripts}

Erasmus's handwriting could be difficult even for experts at the time. In 1515 Nikolaus Gerbel, working as a proof reader of Erasmus's Lucubrationes for Schürer in Strasbourg, lamented this gently: "There is only one thing I am really afraid of -that you will say I am very poor diviner: in reading your writing I have so often been compelled to guess. It often happens that I have to torture this thick head of mine in all directions before I can discern what to call some things by." ${ }^{63}$ When hiring famuli Erasmus cared that they knew Latin and could write; he praised one young helper named Louis for his loyalty and diligence and for writing with ease and elegance. ${ }^{64}$ Indeed it is easy to identify their neat Italic by contrast with Erasmus's scrawl, for example in working copies of the Adages which were annotated in preparation for a later edition.

Even as Erasmus relied on amanuenses, he also lamented the practice in De recta ... pronunciatione (1528), in which he blamed printing for a decline of autography and recommended handwriting as an essential humanist skill:

Lion: But now, with the existence of printing it has come about that some scholars never write at all. If ever they do decide to put their thoughts on paper, their artistry is so marvelous that they often fail to make out what they have written and they have to get a secretary to read and recognize what they cannot! Why, many

...Gilberti Cognati adagiorum sylloge (Basel: Episcopius, 1574) in Irmgard Bezzel, Erasmus-Drucke des 16. Jahhunderts (Stuttgart: Anton Hiersemann Verlag, 1979), 65 \#98.

${ }^{63}$ Ep. 349 (31 August 1515, from Nicholaus Gerbellius); tr. Mynors and Thomson, CWE 3 (1976), 168. I am grateful to William Barker for this reference. Similarly Lipsius had such difficult handwriting that his printers Plantin and Moretus had some of his manuscripts copied again in order to be legible to the compositor and assigned to others a particular compositor who could read his writing; see Grafton, The Culture of Correction, $164,166$.

64 "Eruditionem nihil moror, modo sciat Latine, et scribat vtcumque." Ep. 2916 (13 March 1534, to Cornelius Grapheus), 11.10-11. "Tum scribit et expeditissime et polite, Gallice simulque Latine.” Ep. 135 (November 1500 to Jacob Batt), 11. 35-39. Bierlaire 29, 20. 
of them copy the practice of princes, and employ secretaries for writing letters. But what will they do when they want their letters to be secret, as kings often do? ... A letter written by a third party hardly deserves to be called a letter at all. Secretaries often make their own changes. Even if you dictate rigidly, intimacy will still be missing. Some things you will express differently, some things not at all. So it is no longer a free discussion with a friend. And that leaves out the question of authenticity. Appending a signature is easy, to forge a whole letter very difficult indeed. Just as individual voices differ, so does every handwriting have something unique about it. ${ }^{65}$

In fact Erasmus wrote most of his letters himself. Sometimes a famulus wrote out the address on the envelope. Only occasionally did one write the whole letter.

Gilbert Cousin penned a few letters for Erasmus. In one case he copied a letter already sent to Sadoletus in order to share it with Boniface Amerbach; then he appended a paragraph in Erasmus's voice, followed by a note in his own voice explaining that Erasmus was suffering from gout in the hand and thus unable to write. ${ }^{66}$ Another of these was addressed to Pope Paul III; since it was dated only two months later perhaps the gout was striking again, although illness is not mentioned in this more formal and impersonal letter. ${ }^{67}$ Alternatively Erasmus may have used an amanuensis as a mark of politeness, in keeping with the habits that James Daybell has documented among English letter-writers ca 1600 who wrote in their own hand letters to family, peers, and friends, while using a secretary to write to those both higher and lower in the social hierarchy. ${ }^{68}$ One month after that Erasmus again complained of his gout in a letter to his friend Piotr Tomicki in Poland, but in mentioning his use of a secretary he also absolved his amanuensis of blame for any errors: "PS excuse me for using another's hand. The gout prevents me from even signing. If my secretary has written with negligence it's because the messenger was in a hurry and he did not have time to make a clean copy." $" 69$ This unusual apology exonerated the scribe while blaming the haste of another one of the people on whom Erasmus relied in his correspondence-- the courier.

${ }^{65}$ ASD I-4, 34, 11. 666-70, 676-80, 683-84; tr. Maurice Pope, CWE 26 (1985), 391. See also A. S. Osley, Scribes and Sources: Handbook of the Chancery Hand in the Sixteenth Century (Boston: David Godine, 1980), 29-30. Erasmus's conception of the letter as making present an absent friend resembles Jerome's; see Barbara Conring, Hieronymus als Briefschreiber: Ein Beitrag zur spätantiken Epistolographie (Tübingen: Mohr Siebeck, 2001), 85ff.

${ }^{66}$ Ep. 2971 (31 October 1534 to Sadoletus and to Amerbach).

${ }^{67}$ Ep. 2988 (23 Jan 1535 to Pope Paul III); Gerlo and Foriers offer the hypothesis about gout.

${ }^{68}$ James Daybell, The Material letter in early modern England. Manuscript letters and the culture and practices of letter-writing 1512-1635 (Houndmills: Palgrave Macmillan, 2012), 86-88. This hypothesis about hierarchy is hard to test. No other letter by Erasmus to Paul III survives; letters to Leo X, Henry VIII, James V of Scotland survive, but in printed form or later copies.

${ }^{69}$ Ep. 3000 (28 Feb 1535 to Piotr Tomicki); see Bietenholz and Deutscher, III, 327-29. 
These cases are prime examples of the kind of help that early modern authors were most likely to acknowledge: the author suffering from illness (e.g. gout or eye trouble) employed a young man to take down his words. This is the type of interaction which Gilbert Cousin memorialized in a 29-page pamphlet he published almost twenty years later entitled "Image of Erasmus and his amanuensis." shown filling the "thirsty sheets" with dictation, as one of the many poems in the booklet celebrates. ${ }^{71}$ We should bear in mind that just as the many portraits that Erasmus commissioned of himself were idealized, this one may be too, by Gilbert Cousin. The woodcut was reportedly copied from a fresco on the wall of Cousin's house which was still visible in 1779 , but no longer today. ${ }^{72}$

Amanuenses also performed other kinds of work. They corrected proof: Nepos and Menard de Hoorn were sent to Basel in 1518 to correct proof for a new edition of the Novum instrumentum..$^{73}$ A surviving copy of Erasmus's Apologiae (1522) is annotated with additions by Erasmus and numerous editorial annotations by Nicolaas Kan. ${ }^{74}$

Amanuenses collated. Erasmus explained in 1523 to Johann Vlatten that since the printers were pressuring him to add something to an edition of the Tusculan Disputations of Cicero, he let his famuli do the collating of the different versions of the text and instead intervened on difficult questions, in particular about the Greek and Latin poets that Cicero cited. Erasmus then described how in cases of divergence "we" made decisions (variously to adopt the most common reading or to leave both readings, providing one in the text and one in the margin). To what extent can the plural of a pronoun-here the shift from "I" and "they" to "we" -be interpreted as offering insight into the dynamics of this work? Elsewhere Erasmus mocked the plural as a form of

${ }^{70}$ Effigies Des. Erasmi ... et Gilberti Cognati eius amanuensis (Basel: Oporinus, [1553]).

${ }^{71}$ See the poem by Joost Sasbout: "ut bibulas pinxit chartas, dictante magistro" ("Just as he filled the thirsty sheets under the dictation of the master") Effigies, f. 29r.

72 The image presumably depicts the setting in the Freiburg years. Patrizia Armandi, "Erasmo a Rotterdam e i libri. Storia di una bibliotheca," in Bibliothecae selectae : da Cusano a Leopardi / a cura di Eugenio Canone (Florence: Olschki, 1993), 13-72, p. 31. There Erasmus at first lived in a house built for the emperor, "Zum Walfisch," then moved to a house he bought, "Zum Kindlein Jesu"; Hoyoux, 18. The fresco is mentioned in Romain Joly, La Franche-Comté ancienne et moderne... Lettres a Mlle d'Udressier (Paris: Herissant et Barrois, 1779), 55 (although the clothing described there is not a perfect match to the printed image). For an entry into the literature on portraits of Erasmus see Alexandre Vanautgaerden, Autoportraits d'Erasme (Turnhout: Brepols, 2010).

73 Bierlaire, 31.

${ }^{74}$ Erasmus, Apologiae adversus eos, qui illum locis aliquot in suis libris non satis cicumspecte sunt calumniati (Basel: Froben, 1522), Cambridge University Library Adv.a.5.1. Discussed in Jardine, 24-25 and Henk Jan de Jonge, "Aantekeningen van Erasmus in een exemplaar van zijn Apologiae omnes," Nederlands Archief voor Kerkgeschiedenis, 58, 2 (1978), 176-89. 


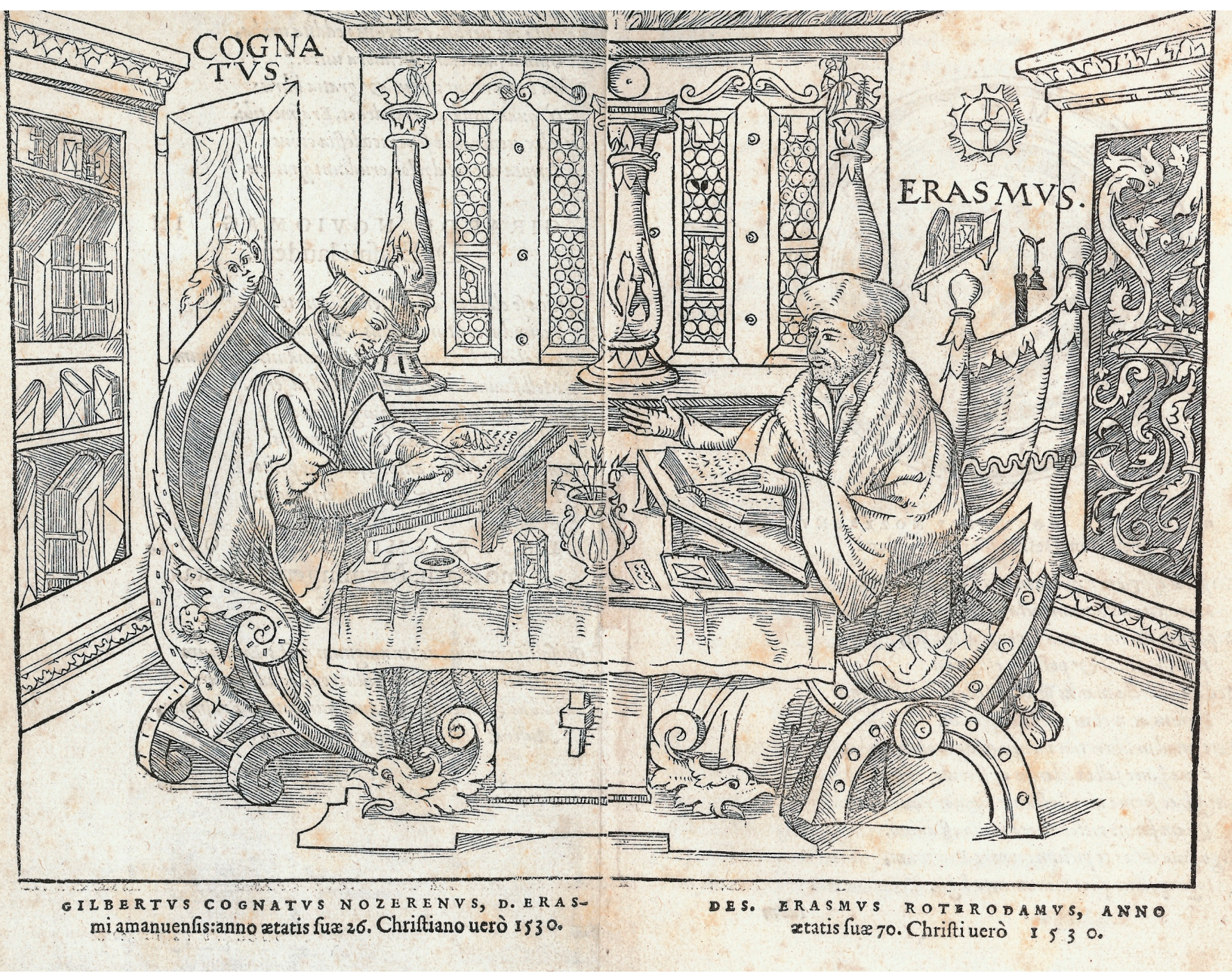

Figure 1

The centerpiece of Effigies Des. Erasmi ... et Gilberti Cognati (Basel: Oporinus, 1553), pp. 8-9, published by Cousin seventeen years after Erasmus' death Reproduced by kind permission of the Universitätsbibliothek Basel, call number AN VI 4a (digitized on E-rara.ch) 
politeness. But translators have typically ignored the passage from "I" to "we" in authorial statements, viewing them as choices of style rather than clues about working methods. $^{75}$

Erasmus and his amanuenses worked together, although in what sequence and setting we probably cannot tell. Two surviving copies of the Adages were working copies bearing annotations by both Erasmus and Nicolaas Kan: one copy of the edition of 1523 with annotations toward the edition of 1526, and one of 1526 with additions toward the edition of 1528. Neither set of annotations matched the final version that was printed, so these working copies represent an intermediate stage in the preparation of the new editions. Nonetheless we can conclude that Erasmus and Kan both worked on the indexes and the text of these two editions of the Adages. In the copy from 1526 Kan worked especially on the first index of adages in alphabetical order-reordering adages to improve alphabetization and the form of the adage in the index, and eliminating duplication (Image 2). Kan also added text in the margins and on slips tipped into the back of the volume, but we do not know whether he wrote under dictation or direction to excerpt a source, or possibly from his own research and initiative even though Erasmus claimed to disapprove of such independence from a helper. In the copy of 1526 Erasmus worked on the "second index" by commonplace headings, adding new headings and new adages in existing headings (Image 3). In both working copies Erasmus also added text in the margins (including, in 1523, the sentence in "Dimidium plus toto" about which he complained) and on slips. ${ }^{76}$ Erasmus and Kan thus worked together on two iterations of

${ }^{75}$ Consider the changes in first person pronouns in this passage: "Itaque conferendorum exemplarium negocio famulis delegato, iudicandi parteis mihi sumpsi; totoque opere non oscitanter perlecto, digessi versus carminum, quae ille quidem non sine exemplo Platonis et Aristotelis ex Graecis Latinisque poetis, sed propemodum ad taedium vsque, congerit, Ubi variabant exemplaria, vel quod probabatur amplexi sumus; vel, si videbatur anceps iudicium, vtranque lectionem seruauimus, alteram in contextu, alteram in spatio marginis. Nonulla citra codicum suffragium restituimus, sed nec admodum multa, et ibi duntaxat vbi res homini docto et exercitato non esset obscura: nonnihil etiam scholiorum adiecimus." Ep. 1390 (October 1523, preface to Cicero's Tusculanae quaestiones, addressed to Johann von Vlatten), 11. 6-16. Neither Mynors nor Gerlo respect the variations between singular and plural here, though Bierlaire does (p. 31). On Erasmus's rejection of the growing trend of using the second person plural as a more formal address (at least in Latin) see Alexander Dalzell, "Greetings and Salutations in Erasmus,"

Renaissance and Reformation. Renaissance et Réforme. n.s. 13:3 (1989), 251-61, p. 25455. Erasmus devised a similar arrangement for editing Seneca: he delegated the task to Beatus Rhenanus, while Wilhelm Angst did the actual correcting in Basel, with a daily visit from Rhenanus to answer hard questions; Grafton, Culture of Correction, 105. ${ }^{76}$ For more discussion and illustrations from the copy of 1526 see Luigi Michelini Tocci, In officina Erasmi: l'apparato autografo di Erasmo per l'edizione 1528 degli Adagia e un nuovo manoscritto del compendium vitae (Rome: Edizione di Storia et Letteratura, 1989), and Ann Blair, "Indexing: a mechanical or a liberal art?" forthcoming in a volume ed. Dennis Duncan. The working copy of Adagiorum opus (1526) is Vatican ms Chig. R VIII 62. The working copy of [Adagiorum opus] (Basel: Froben, 1523) was sold by Sotheby's 


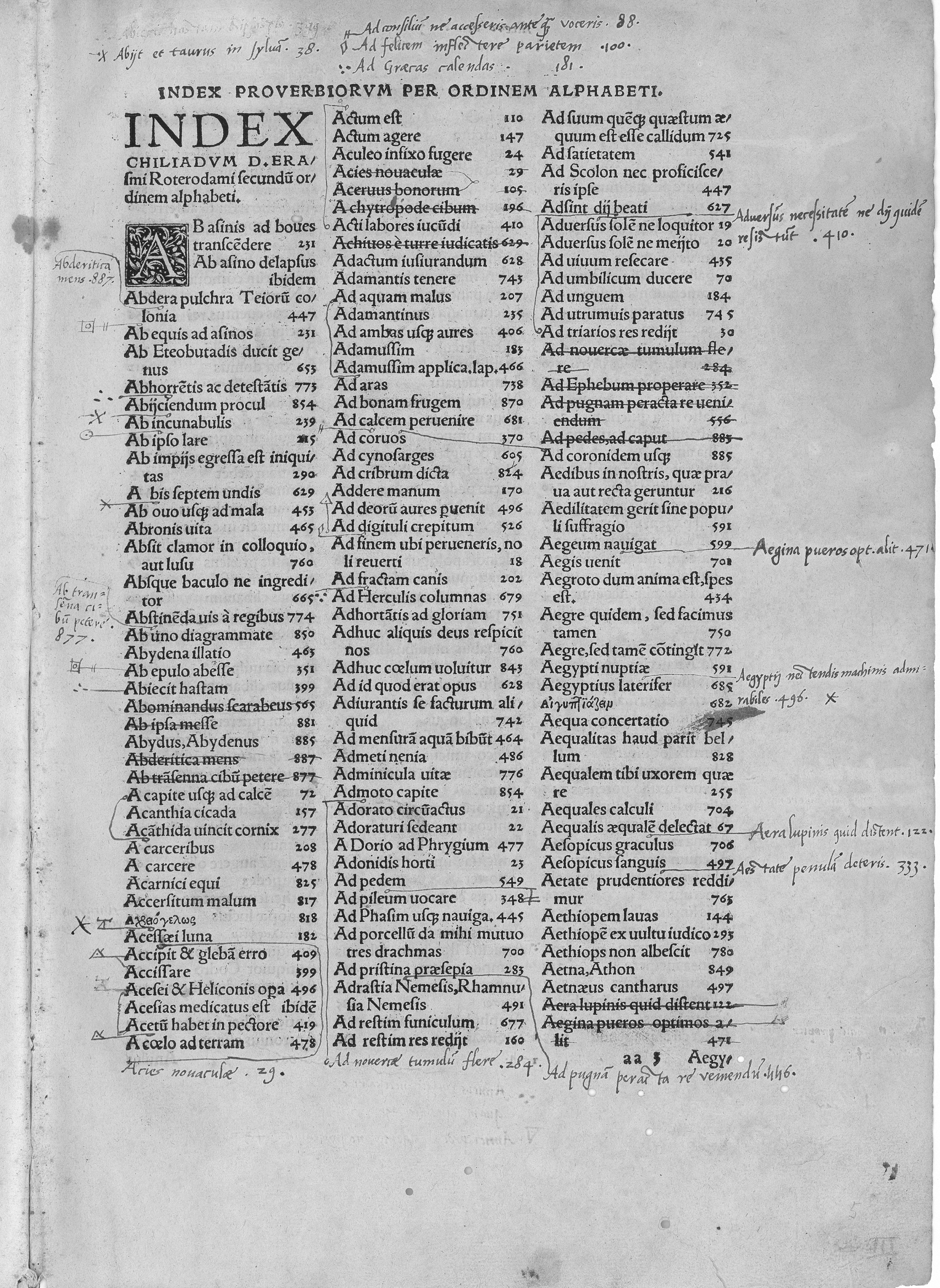

Figure 2: Opening of the first index in the working copy of Adagiorum opus (1526), showing additions and rearrangements in the neat italic hand of Nikolaas Kan who was Erasmus' amanuensis 15241530 and during the period of this work (1526-1528) Reproduced with permission of the Vatican Library from Chigi R VIII.62, f. 3r 

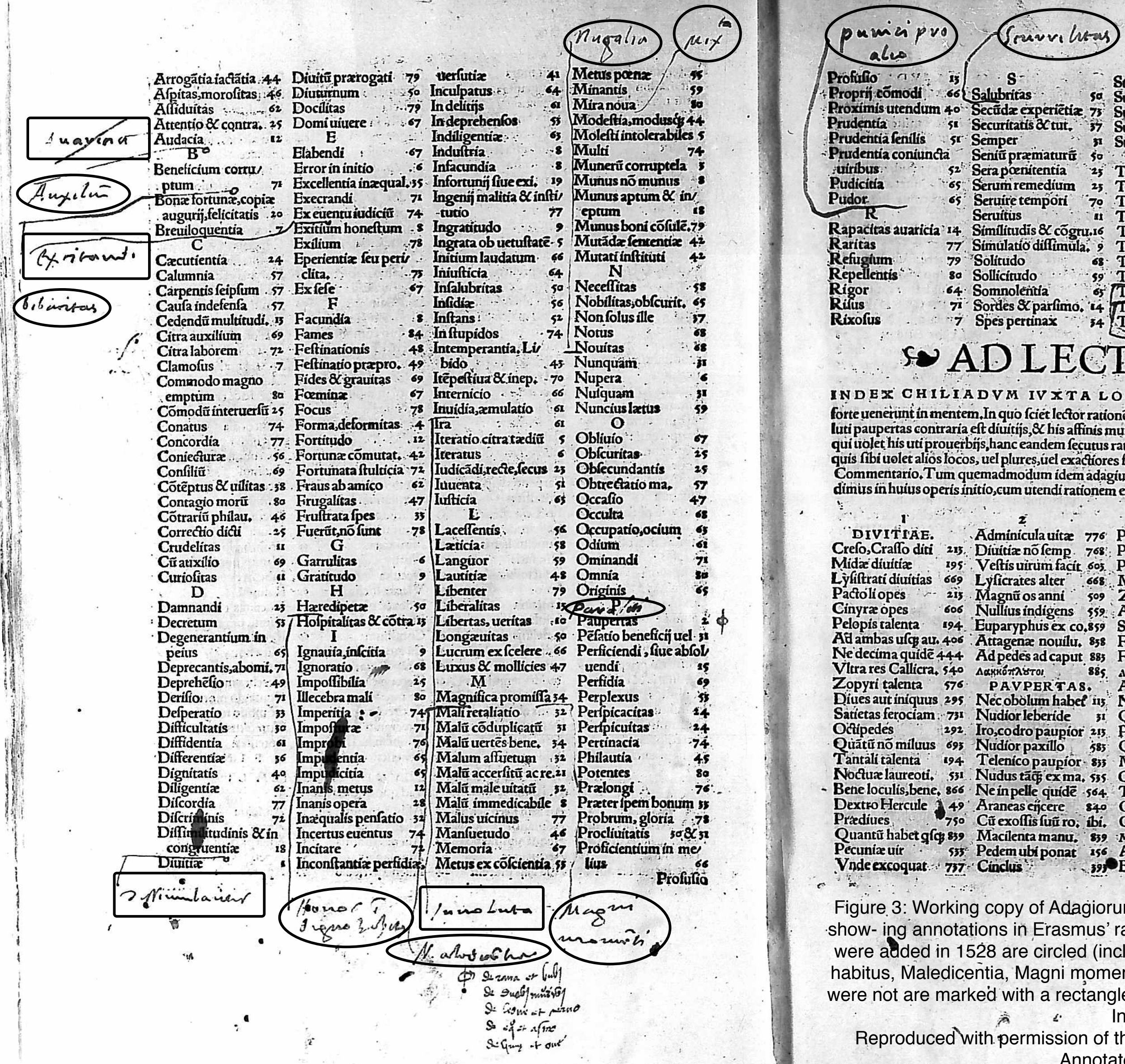

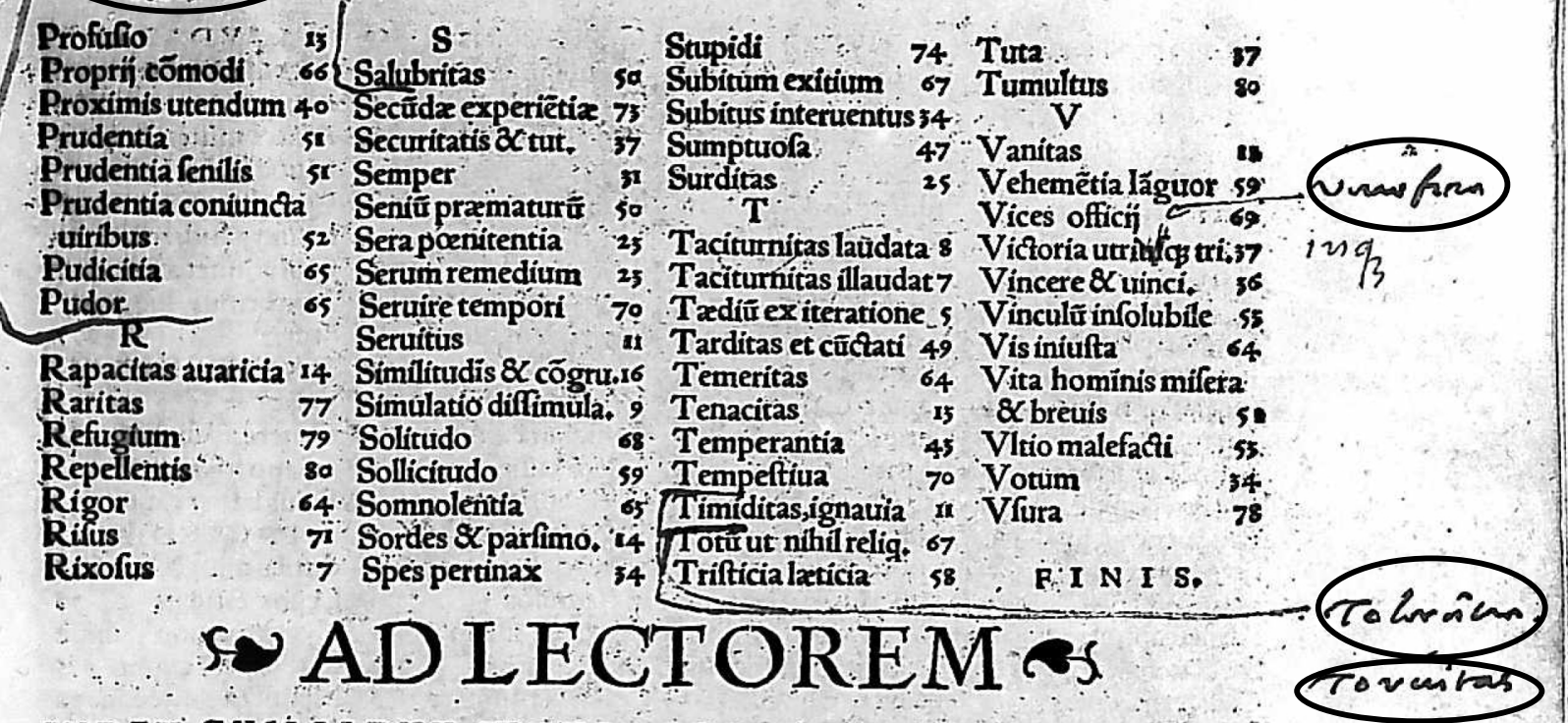

INDEX CHILIADVM IVXTA LOCOS ET MATERIAS,VTTVM

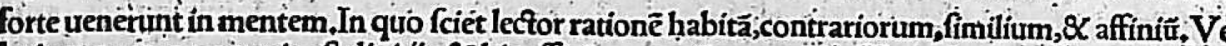
luti paupertas contraria eft diuitins, $Q \mathrm{C}$ his aftinis munerü corruptela. Hoc admonendü putautiquo qui itolet his uti proureerbis, hanc eandem fecutus rationem facilius quod quxrit, inueniat, Quod quis fibin Commention fenfus accommodari poffit, oftery

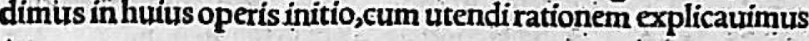

DIVIT'AaE. Adminiculauita 776 Piftilo nudior 854 Bouê in faurcibus 405

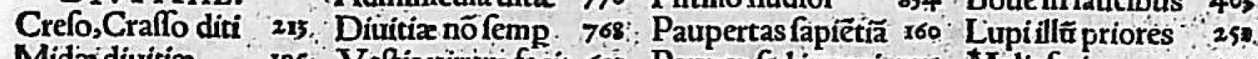

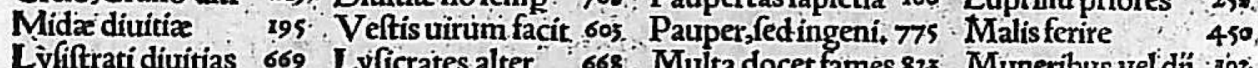
Lyffifrati diuitias 669 Lyficrates alter 668 . Multa docet fames 825 Muneribus uel dil a.jo

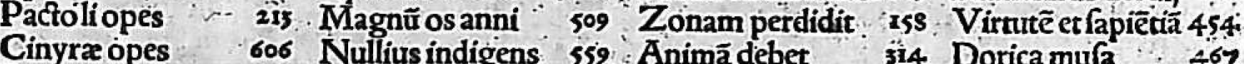
Cinyra opes 606 Nulliusindigens 559 : Anumet 50 : Pecunia obediüt 12 Alambas ufa au, 406 . Euparyphus ex c0,859 Saguntialames bide Mumerü corrupted. 76

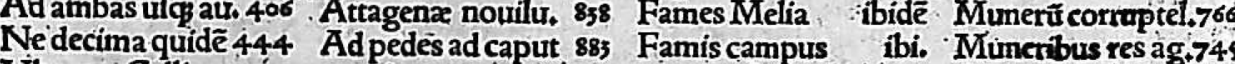

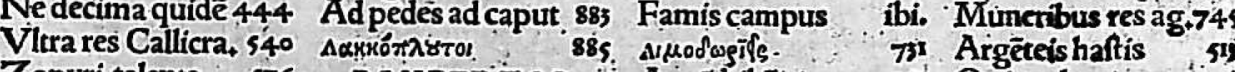

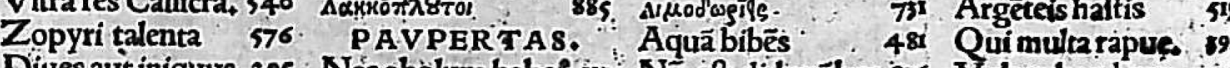
Dats

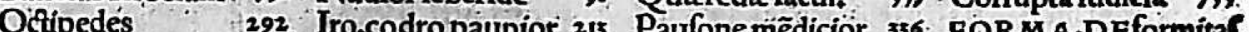
Ouătũ nốmiluus 693 Nứdior parillo Tantali talenta 194 Telenico paupior-855 Mendiconepare 825 A funisoriundus 85

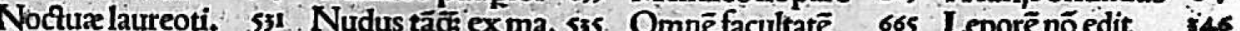
Beheloculis, bene, 866 . Ne in pelle quidē .564. Theagenis pecur, 547 Mýconius caluus 34 DextroHercule 149. Araneas encere 840 Cleomenesfupat 835 Pittilo calurior Præ̉diures 750 Cũ exoffis fuũ ro, ibi. Certiffima paupt, 878 Multăfyluá geft. 701 Quantũ habet gfọ,859 Macilenta manu, 839 MVNErũ corruptela. Pronomibarba, 818

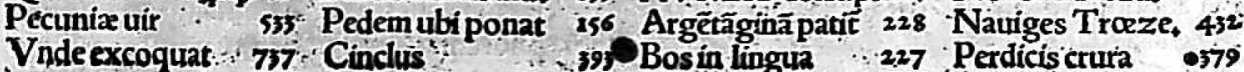
Vnde excoquat 777 Cinclus 39 Bosin lingua 227 Perdiciscrura

Figure 3: Working copy of Adagiorum opus (1526), full opening of ff. $16 \mathrm{v}-17 \mathrm{r}$ show- ing annotations in Erasmus' rather difficult hand. Those headings which were alded in 1528 are circled (including Auxilium, Bibacitas, Honos indigno habitus, Maledicentia, Magni momenti, Mixta, Nugalia); those headings which were not are marked with a rectangle (e.g. Avaritia, Dis- simulantes, Excitandi,

Reproduced with. permission of the Vatican Library from Chigi R VIII.62. Annotated in Preview 
the same text, whether at the same time, with ongoing conversations, or quietly and separately we cannot tell.

Of course most of this collaboration between Erasmus and his amanuenses is lost -all the oral interactions, the details of when and where, and many working papers too.

Manuscripts entirely in the hands of helpers may well have been judged uninteresting at some point along the long line of transmission and discarded or reused as waste paper, e.g. in bindings. Nonetheless Cousin's manuscripts survive in good numbers in Basel because he beame a humanist in his own right, with strong connections to the city where he worked with Erasmus.

Cousin published a short treatise on servants entitled Oiketes in 1535 (the dedication was dated May, and the imprint from August of the year in which he left Erasmus's employ). And he alone of all the familiares contributed an epitaph to Erasmus in a memorial volume published in 1537 by Froben. ${ }^{77}$ Cousin's copy of the 1553 Effigies booklet is extant in the Basel library, stuffed with even more poems (mostly manuscript, with a few cut from printed sources) that he inserted in his copy, perhaps in view of a later edition which never materialized or just to keep track of them. Cousin founded a preparatory school in Nozeroy and attracted the sons of some of his Basel contacts, including the printer Henricpetri and the corrector Sigismundus Gelenius. ${ }^{78}$ Cousin shared information about Erasmus and himself with Conrad Gessner and Josias Simmler who included it in the Bibliotheca (1545) and the Epitome of 1555 respectively, with explicit thanks. ${ }^{79}$ Cousin was himself a prolific author-several dozen works of his survive, many of them

in 1990 and is now in private hands; see ASD II-7, ed. R. Hoven (Amsterdam: Elsevier, 1999), 3 and note 55 above. On the indexes of Erasmus's Adages see the invaluable "Indexes to Erasmus' Adages," tr. William Barker, CWE 30 (2016), 367-778.

${ }^{77}$ Catalogi duorum operum Erasmi ... accessit in fine epitaphiorum ac tumulorum libellus (Basel: Froben, 1537), 118 (on the next to last page, before Sebastian Münster's closing tribute in Hebrew).

${ }^{78}$ On Cousin, see Febvre (note 33); Pierre-André Pidoux, "Un humaniste comtois: Gilbert Cousin, Chanoine de Nozeroy, Secrétaire d'Erasme (1506-72)," Mémoires de la Société d'Emulation du Jura 8e s. vol. 4 (1910), 35-147; Peter Bietenholz, Basle and France in the sixteenth century; the Basle humanists and printers in their contacts with Francophone culture (Geneva: Droz, 1971), 234-40, 279-82; and, as the owner of a copy of Heroica Philostrati, Jeanne Veryin-Forrer, "Une copie utilisée par l'imprimeur Heinrich Petri' in La lettre et le texte. Trente années de recherches sur l'histoire du livre, Collection de 1'Ecole Normale Supérieure de Jeunes Filles 34 (Paris: ENS boulevard Jourdan, 1987), 321-38.

${ }^{79}$ Conrad Gessner, Bibliotheca universalis (Zurich: Froschauer, 1545), 275v-276r; Cousin is credited with sending Gessner with a list of Erasmus's books. Cousin is also listed as a source elsewhere, e.g. in the entry for Arnoldus Oridyrus (93r). In the 1555 Epitome which served as a sequel, Josias Simmler appended a "Paralipomena", 183r$184 \mathrm{v}$, including recent publications transmitted by Cousin, but which had arrived too late for insertion in the alphabetical sequence of the text itself. 
religious and pedagogical texts, in small formats (octavo and duodecimo). ${ }^{80} \mathrm{He}$ also published a handful of folios, including his Opera omnia in three volumes printed by Henricpetri, which gathered many poems and letters, although interestingly not his image of him working with Erasmus. It was not easy being an Erasmian in France during the wars of religion: Cousin was arrested on suspicion of heresy, and died in prison in 1572 . Otherwise we have almost no other writings by Erasmus's familiares. ${ }^{81}$

\section{CONCLUSION}

Erasmus felt there were drawbacks to delegation -loss of privacy, the need to trust others, the risks of unauthorized publication or interpolation-- but clearly on balance he could not live without his helpers who enabled him to complete and publish dozens upon dozens of new works, editions, and translations with remarkable quality and speed. They were a crucial source of labor, some of which we might consider mechanical, but much of which required a good education and personal judgment as Erasmus acknowledged from time to time. Erasmus cultivated a large network of correspondents, but his republic of letters started at home, with members of his household, who learned there the habitus of the humanist scholar and helped to spread Erasmus's values and reputation in their further careers. Erasmus's relatively many references to his famuli, in his letters and occasionally in print, could also motivate a further supply of young men desirous of entering his household. Little remains of these relationships beyond representations of them made for various purposes, to celebrate one's connection to a great scholar (as in Cousin's woodcut) or to pin responsibility for errors on someone else (as in Erasmus's complaints).

One of the most vivid remains of these relations are the books involved which have survived-books by Erasmus, some of them proudly recorded as gifts to his familiares, and then annotated. Nesen's copy of the Adages (1508), annotated for his own use it seems, is now in the Princeton University Library. Kan recorded the gifts by Erasmus of both the working copies of the Adages from 1523 and $1526 .{ }^{82}$ A volume at the Folger Library is Cousin's copy of Erasmus' Epistolae Palaeoneoi, 1532-bearing two

${ }^{80}$ Pierre-André Pidoux lists 63 surviving imprints and a further fifteen texts, either printed or manuscript, which have not survived in his "Bibliographie historique des oeuvres de Gilbert Cousin," Le bibliographe moderne 15 (1911), 132-71.

${ }^{81}$ Pierre du Chastel (Castellanus), who worked with Erasmus briefly in 1527, published an account of the death of Francis I in 1547; Bierlaire, 76-77; Bietenholz and Deutscher, I, 409-10.

82 "Sum Nicolai Cannii senioris et amicorum" and "Sum Nicolai Cannii ex liberalitate mei praeceptoris Erasmi Rotterodami." Adagiorum opus (Basel: Froben, 1523), copy in private hands, title page and p. [806] (at the end of the errata). "Cannius est dominus, sed magni munere Erasmi.” Adagiorum opus (Basel: Froben, 1526), Vatican Chigi R.VIII.62, title page. Later inscriptions there track Cannius's gift of the book to Johann Gropper in 1552, then its ownership by David Warneking in Osnabrück, followed by his son Victor Warneking in Paderborn, and by the son-in-law of Victor, Johann Hoffman; see Luigi Michelini Tocci, In officina Erasmi, 12-23. The annotated copy of the Apologiae (1522) in the Cambridge University Library bears the names of both Erasmus and N. Cannius. 
inscriptions: from Cousin to Sigismundus Gelenius whom he calls "praeceptor" presumably to signal the respect due him as his senior and an expert scholar; then from the Basel printer Johannes Oporinus (who evidently owned it after Gelenius) to Heinrich Billing, a Zurich patrician (Image 4). ${ }^{83}$ These books were worth something in their day, commercially and sentimentally. And they have new significance today as we strive to reconstruct not only working methods but also the human relationships they involved. ${ }^{84} \mathrm{I}$ hope we can find more such books and relationships in the research ahead.

${ }^{83}$ Erasmus, Adagiorum chiliades tres (Venice: Aldus, 1508), Princeton University Library (EX) 7183053Q. Erasmus, Epistolae palaeonaeoi (Freiburg: Joannes Emmeus Juiliacensis, 1532), Folger Library copy PA8511.A3.1532. Heinrich Billing, stepson of Zurich Bürgermeister Jakob Meyer, was the dedicatee of Gessner, Historia plantarum (Basel: R Winter, 1541).

${ }^{84}$ For a rich new history of emotions in scholarship, see Françoise Waquet, Une histoire émotionnelle du savoir (Paris: CNRS Editions, 2019). 


\section{DESIDERII ERASMI}

ROTERODAMI, EPISTOLAE PALAEONAEOI.

A D H A E C

RESPONSIO AD DISPVTATIONEM EVIVSDAA

PHIMOSTOMI, DE DIVORTIO.

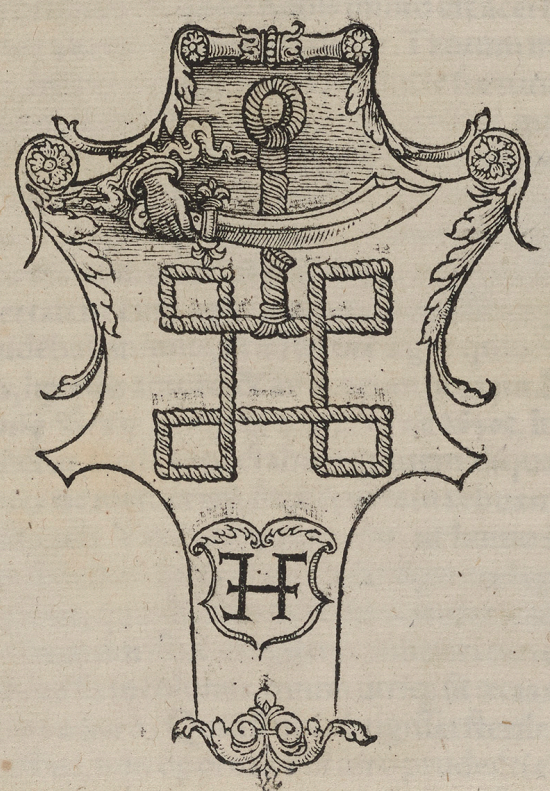

D. Sigifmunds Gelonio praceptori we Gulberfus Cogmatit Noferefenfis domo mijif.

FRIBVRGI BRISGOIAE APVD IOANNEAL EMMEVM IVLIACENSEM, MENSE SEPTEMBRI. AN: M. D. XXXII.

D. Henciro Billingis Suo, ansiro pimazio, loan. Opozinsis D.D.

Figure 4: Copy of Erasmus' Epistolae Palaeoneoi, 1532 bearing Cousin's original inscrip- tion "to his praeceptor Sigismundus Gelenius," and the inscription that was later pasted overit. from the printer "loannes Oporinus to his great friend Heinrich Billing," a patrician of Zurich

Reproduced with kind permission of the Folger Library from PA8511.A3.1532 